\title{
KEABSAHAN FENOMENA PERKAWINAN JAM'U BAINAL UKHTAIN MENURUT HUKUM PERKAWINAN DI INDONESIA
}

\author{
Ilham Abdul Kholid \\ Fakultas Syariah dan Hukum UIN Sunan Gunung Djati Bandung \\ Email : abdulkholidilham@gmail.com
}

\begin{abstract}
Islam has arranged marital affairs as well as possible, including the prohibition of marrying two female siblings at the same time or what is called jam'u bainal ukhtain. Although the ban was clear, the phenomenon of the marriage of jam'u bainal ukhtain still occurred between a man who married two female siblings at once, namely between $A(L)$ and $N(P)$ his brother, then I $(P)$ his sister in the village Sukasenang Banyuresmi District, Garut Regency. This study aims to determine the background of the marriage of jam'u bainal ukhtain, the process of conducting the marriage jam'u bainal ukhtain, and the legal consequences of the marriage of jam'u bainal ukhtain which occurred in Sukasenang Village, Banyuresmi District, Garut Regency. The research method used in this study is a case study by collecting data through interview techniques and literature studies. Based on the data obtained, it was found that the cause of the marriage of Jam'u bainal ukhtain was the mistaken belief regarding adat ngarunghal (overtaking), along with the lack of religious knowledge and lack of education. In addition, identity concealment was also found. The process of the first marriage between $\mathrm{A}$ and $\mathrm{N}$ is carried out openly and has fulfilled the pillars and terms of marriage, then the second marriage between $\mathrm{A}$ and $\mathrm{I}$ is carried out in a closed manner because it is clearly prohibited and unlawful. This form of marriage results in illegitimate marriages between $A$ and $I$, so that the relationship between husband and wife is done with zina. The ARanak born from the marriage only has civil relations with the mother and family of the mother only, and there is no nasab rights and inherits each other between A and AR.
\end{abstract}

\section{Keywords :}

jam'u bainal ukhtain, marriage is not legal, civil relations

\begin{abstract}
Abstrak
Islam telah mengatur urusan perkawinan dengan sebaik-baiknya, termasuk adanya larangan menikahi dua saudara kandung perempuan sekaligus atau yang disebut dengan jam'u bainal ukhtain. Walaupun telah jelas larangannya, fenomena perkawinan jam'u bainal ukhtain tetap saja terjadi antara seorang laki-laki yang menikahi dua orang perempuan saudara sekandung sekaligus, yaitu antara $A(L)$ dengan $N(P)$ kakaknya, kemudian I (P) adiknya di Desa Sukasenang Kecamatan Banyuresmi Kabupaten Garut. Penelitian ini bertujuan untuk mengetahui latar belakang terjadinya perkawinan jam'u bainal ukhtain, proses pelaksanaan perkawinan jam'u bainal ukhtain, dan akibat hukum dari perkawinan jam'u bainal ukhtain yang terjadi di Desa Sukasenang Kecamatan Banyuresmi Kabupaten Garut. Metode penelitian yang digunakan penelitian ini adalah studi kasus dengan pengumpulan data melalui teknik wawancara dan studi kepustakaan. Berdasarkan data yang diperoleh ditemukan bahwa penyebab perkawinan jam'u bainal ukhtain tersebut adalah adanya keyakinan yang keliru mengenai adat ngarunghal (mendahului), disertai minimnya pengetahuan agama dan kurangnya pendidikan. Di
\end{abstract}


samping itu ditemukan pula penyembunyian identitas. Proses pernikahan pertama antara $\mathrm{A}$ dengan $\mathrm{N}$ yang dilakukan secara terbuka dan telah memenuhi rukun dan syarat pernikahan, kemudian pernikahan kedua antara A dengan I yang dilakukan secara tertutup karena jelas pernikahan tersebut dilarang dan haram hukumnya. Bentuk pernikahan seperti ini mengakibatkan tidak sahnya perkawinan antara A dan I, sehingga hubungan suami istri yang dilakukan sama dengan zina. Adapun ARanak yang dilahirkan dari perkawinan tersebut, hanya memiliki hubungan keperdataan dengan ibu dan keluarga ibunya saja, serta tidak ada hak nasab dan saling mewarisi antara A dengan AR.

\section{Kata Kunci : \\ jam'u bainal ukhtain, perkawinan tidak sah, hubungan keperdataan}

\section{Pendahuluan}

Dalam kehidupan manusia, perkawinan merupakan peristiwa penting dalam kehidupan manusia, tidak hanya mempersatukan dua insan, namun juga menghubungkan dua keluarga besar bahkan masyarakat. la merupakan peristiwa yang suci mengingat kentalnya kaidah agama yang tidak hanya meliputi prosesi perkawinan, namun juga sepanjang hidup kedua mempelai.

Pada hakikatnya, perkawinan merupakan sunnatullah yang berlaku tidak hanya pada manusia, namun pada hampir seluruh mahkluk hidup. Perkawinan merupakan salah satu cara bagi makhluk hidup untuk mendapatkan keturunan. Adapun bagi manusia, Allah melalui hukumnya menjaga kehormatan dan martabat kemuliaan manusia, sehingga hubungan antara laki-laki dan perempuan diatur secara terhormat berdasarkan rasa saling meridhai yang ditandai dengan upacara ijab kabul sebagai lambang adanya rasa ridha-meridhai, dan dihadiri para saksi yang menyaksikan bahwa laki-laki dan perempuan tersebut telah saling terikat. ${ }^{1}$

Dalam hal ini, perkawinan merupakan salah satu ibadah, sehingga salah satu tujuan pelaksaannya adalah untuk mengharapkan keridhaan Allah SWT., sebagaimana dijelaskan dalam firman Allah dalam surat Ar rum ayat 21 yang berbunyi:

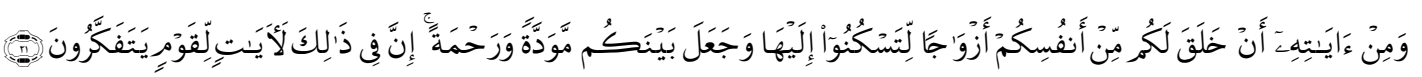

"Dan di antara tanda-tanda kekuasaan-Nya ialah Dia menciptakan untukmu istriistri jenismu sendiri,supaya kamu cenderung dan merasa tentram kepadanya, dan dijadikan-Nya diantaramu rasa kasih dan sayang. Sesungguhnya pada yang demikian itu benar-benar terdapat tanda-tanda bagi kaum yang berfikir."

Dalam pasal 1 Undang- Undang nomor 1 tahun 1974 tentang Perkawinan (UU Perkawinan) dikatakan bahwa: "Perkawinan adalah ikatan lahir batin antara seorang pria dengan wanita sebagai suami isteri dengan tujuan membentuk keluarga (rumah tangga) yang bahagia dan kekal berdasarkan Ketuhanan Yang Maha Esa".

\footnotetext{
${ }^{1}$ Abdul Rahman Ghozali, Fiqih Munakahat, (Jakarta, Kencana Prenada Media Group. 2010) hlm. 10
} 
Berdasarkan ketentuan Pasal 1 UU Perkawinan di atas, menurut Hilman Hadikusumo dapat diuraikan bahwa "...sendi-sendi dan unsur-unsur utama dari perkawinan adalah: a) Perkawinan harus dilakukan berdasarkan peraturan perundang-undangan yang berlaku di Indonesia. Keabsahan perkawinan hanya terjadi jika memenuhi syarat formil dan materil berserta prosedur dan tata cara yang ditentukan oleh undang-undang dan peraturan pelaksanaannya. b) Perkawinan mempunyai hubungan erat dengan agama. Agama merupakan sendi utama kehidupan bernegara di Indonesia." ${ }^{2}$

Dalam pasal 8 undang-undang tersebut diatur pula mengenai larangan-larangan perkawinan antara dua orang yang masih berhubungan darah baik lurus ke bawah atau ke atas maupun ke samping, berhubungan semenda, berhubungan sesusuan, atau berhubungan semenda. Di samping itu dilarang pula perkawinan dengan saudara istri, serta yang memiliki hubungan yang dilarang oleh agama atau peraturan lain yang berlaku. Larangan tersebut dalam al Qur'an diatur dalam surat An-Nisa ayat $22-23$, yang berisi:

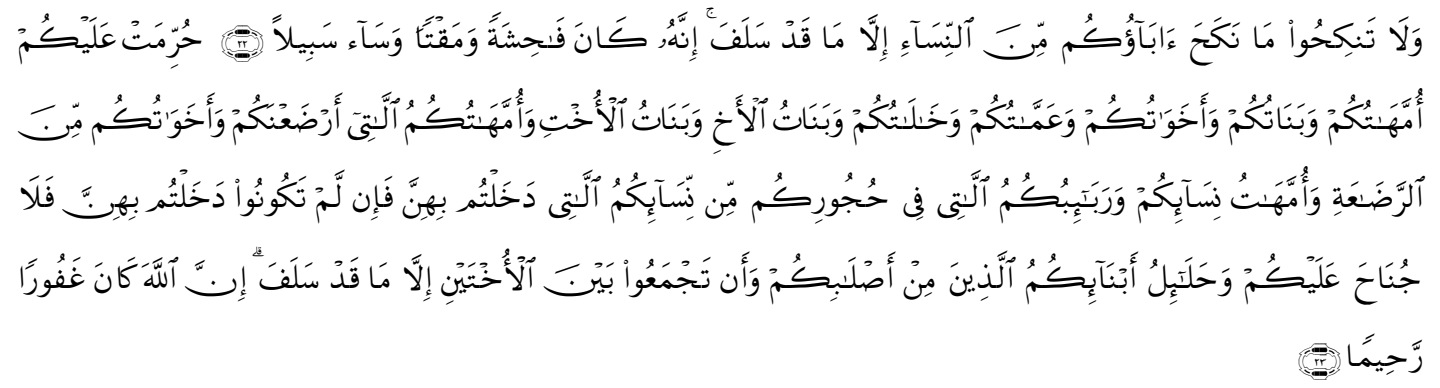

"Dan janganlah kamu kawini wanita-wanita yang telah dikawini oleh ayahmu, terkecuali pada masa yang telah lampau. Sesungguhnya perbuatan itu Amat keji dan dibenci Allah dan seburuk-buruk jalan (yang ditempuh)"

"Diharamkan atas kamu (mengawini) ibu-ibumu; anak-anakmu yang perempuan saudara-saudaramu yang perempuan, saudara-saudara bapakmu yang perempuan ; saudara-saudara ibumu yang perempuan; anak-anak perempuan dari saudarasaudaramu yang laki-laki; anak-anak perempuan dari saudara-saudaramu yang perempuan; ibu-ibumu yang menyusui kamu; saudara perempuan sepersusuan; ibu-ibu isterimu (mertua); anak-anak isterimu yang dalam pemeliharaanmu dari isteri yang telah kamu campuri, tetapi jika kamu belum campur dengan isterimu itu (dan sudah kamu ceraikan), maka tidak berdosa kamu mengawininya; (dan diharamkan bagimu) isteri-isteri anak kandungmu (menantu); dan menghimpunkan (dalam perkawinan) dua perempuan yang bersaudara, kecuali yang telah terjadi pada masa lampau; Sesungguhnya Allah Maha Pengampun lagi Maha Penyayang. ${ }^{3}$

Dalam kompilasi hukum Islam, masalah larangan perkawinan diatur dalam pasal 39, yang menyebutkan bahwa: "Dilarang melangsungkan perkawinan antara seorang

\footnotetext{
${ }^{2}$ Hilman Hadikusuma, Hukum Perkawinan Adat, (Bandung : Citra Aditya Bakti, 1990) hlm. 7

${ }^{3}$ Aam Amiruddin, Al-Quran Al-Mu'asir, Terjemah Kontemporer, (Bandung : Khazanah, Intelektual, 2012) hlm. 77
} 
pria dengan seorang wanita disebabkan: (a) Karena pertalian nasab: 1) Dengan seorang wanita yang melahirkan atau yang menurunkannya atau keturunanny, 2) Dengan seorang wanita keturunan ayah atau ibu dan 3) Dengan seorang wanita saudara yang melahirkannya. (b) Karena pertalian kerabat semenda: 1) Dengan seorang wanita yang melahirkan istrinya atau bekas istrinya, 2) Dengan seorang wanita bekas istri yang menurunkannya, 3) Dengan seorang wanita keturunan istri atau bekas istrinya, kecuali putusnya hubunan perkawinan dengan bekas istrinya itu qobla al dukhul. 4) Dengan seorang wanita bekas istri keturunannya. (c) Karena pertalian sesusuan: 1) Dengan wanita yang sesusuan dan seterusnya menurut garis lurus ke atas. 2) Dengan wanita yang sesusuan dan seterusnya menurut garis lurus ke bawah, 3) Dengan seorang wanita saudara sesusuan, dan kemenakan sesusua ke bawah. 4) Dengan seorang wanita bibi sesusuan dan nenek bibi sesusuan ke atas. 5) Dengan anak yang disusui oleh istrinya dan keturunannya. ${ }^{\prime \prime}$

Penelitian ini berawal dari adanya pernikahan dimana terdapat seorang lelaki yang menikahi 2 saudara perempuan sekaligus, adapun peristiwa tersebut terjadi di desa Sukasenang Kecamatan Banyuresmi Babupaten Garut. Berdasarkan latar belakang di atas, terdapat beberapa hal yang menjadi pokok pembahasan dalam tulisan ini yaitu terkait latar belakang terjadinya pernikahan jam'u bainal ukhtain, tersebut, proses pernikahannya, serta akibat hukum dari pernikahan jam'u bainal ukhtain di desa tersebut.

\section{Metode Penelitian}

Penelitian ini menggunakan pendekatan studi kasus dengan memandang dan medeskripsikan suatu analisis secara utuh, dalam hal ini terhadap perkawinan jam'u bainal ukhtain yang terjadi di Desa Sukasenang Kecamatan Banyuresmi Kabupaten Garut. Lokasi penelitian dilakukan Desa Sukasenang Kecamatan Banyuresmi Kabupaten Garut, adapun alasan penulis memilih lokasi tersebut adalah (a) Berdasarkan pengamatan yang dilakukan pada observasi terlihat bahwa kasus tersebut cukup serius karena tidak ingin terus menerus terjadi kepada keturunan selanjutnya, bahkan anak dari si S ini butuh beberapa tahun untuk menceritakan kasus tersebut dan awalnya juga dia menceritakan ini mengibaratkan kepada orang lain atau tetangga. (b) Adanya keterbukaan dari pihak tokoh masyarakat atau kepala KUA di daerah tersebut.

Adapaun sumber data yang digunakan adalah sumber data primer, yaitu responden yaitu pelaku dan saksi nikah jam'u bainal ukhtain di desa tersebut, serta sumber data sekunder, beruoa bahan hukum primer, didukung oleh bahan hukum sekunder, dan tertier yang dapat membantu menganalisis dan memberikan penjelasan terhadap bahan hukum primer. Jenis data yang dikumpulkan berupa data kualitatif yang diperoleh dari berbagai literatur maupun wawancara langsung dengan responden terkait

${ }^{4}$ R. Subekti dan R. Tjitrousibio, Kitab Undang Undang Hukum Perdata (KUH Perdata), Jakarta : Pradnya Paramita, 2003) 537 
dengan latar belakang, proses, dan akibat hukum dari perkawinan jam'u bainal ukhtain, di Desa Sukasenang Kecamatan Banyuresmi Kabupaten Garut.

\section{Penelitian dan Pembahasan (Pengertian Jam'u Bainal Ukhtain)}

Berdasarkan Fuad Mohd Fachruddin "Al-Jam'u secara etimologi adalah perkumpulan sesuatu. Secara terminologi, al-Jam'u adalah isim yang menunjukkan terhadap lebih dari dua perkara dapat dikategorikan sebagai al-jam'u (baca definisi al-Jam'u atau jamak di sini), meskipun pengistilahannya dalam ilmu nahwu bermacam-macam.. ${ }^{15}$

Menurut Muhammad Bakar Ismail dalam kitabnya Al fiqhul wadih (juz 2:73-81) yang dimaksud dengan aljam'u bainal ukhtain itu adalah menggabungkan antara dua saudara dalam satu keluarga kecuali apa yang telah dilakukan jahiliyah itu dimaafkan, apabila seorang laki-laki menikahi dua saudara, wajib atasnya untuk memisahkan salah satu diantara keduanya sebagaimana diriwayatkan oleh Ahmad bahwa sahabat bernama Fairuz Ad-Dailami masuk Islam dan baginya dua saudara, maka Rasululloh SAW bersabda: ${ }^{6}$

$$
\text { طلق أيتها شئت (رواه أممد) }
$$

"talaklah salah satu diantara keduanya sesukamu" Apabila ia telah mentalak istrinya, maka tidak diperbolehkan baginya, menikahi saudara istrinya kecuali masa iddahnya telah habis.

Menurut Imam As Syafi'i dalam kitabnya Al bayan fi madhabi al imami as syafi'l bahwa pengertian dari aljam'u bainal ukhtain adalah seorang laki-laki menggabungkan pernikahan istri dan saudarinya baik itu saudari sebapak, atau seibu maupun sekandung, baik pula dari segi nasab maupun sepersusuan. Pernikahan tersebut diharamkan karna mengakibatkan istri dan saudarinya saling bermusuhan dan dengki. Maka apabila dibolehkan hal tersebut mengakibatkan terputusnya silaturahmi diantara keduanya, dan tidak ada jalan bagi laki-laki. Itu merupakan ijma dan tidak ada pertentangan didalamnya. Apabila seseorang menikahi istri dan saudarinya bersama sama dalam satu akad maka tidak sah pernikahan salah satu diantara keduanya, karna tidak ada perbedaan diantara pernikahan tersebut.dan batalah pernikahan tersebut, seorang lakilaki menikahi seorang perempuan kemudian menikahi saudarinya dalam pernikahan yang lain maka batalah pernikahan yang kedua karna pengertian aljam'u itu dikhususkan kepada pernikahan kedua. ${ }^{7}$

\footnotetext{
${ }^{5}$ Fuad Mohd Fachruddin, Masalah Anak dalam Hukum Islam (Anak Kandung, Anak Tiri, Anak Angkat dan Anak Zina). CV. Pedoman Ilmu Jaya. 1992, hlm. 15

${ }^{6}$ Muhammad Bakr Ismail, Al-Figh Al Wadhih, Juz 2, (Kairo : Dar al-Manar, 1990) hlm. 73-81

${ }^{7}$ Abul Hasan Yahya bin Abul Khoir bin Salim Al-Imroni, Al-Bayan Fi Madzhabil Imam Asy-syafi'l, Darul Minhaj, (Damaskus-syiria, Cetakan Pertama, 2000, ) hlm. 243
} 


\section{Ketentuan Jam'u Bainal Ukhtain}

Menurut Imam As-Syafi'i dalam kitabnya Al Umm jilid ( 6:7 ), bahwa apabila seorang laki-laki mentalak istrinya dan ia tidak dapat kembali, maka boleh baginya menikahi saudara istrinya, karna ketika itu tidaklah termasuk menggabungkan dua saudara, dan itu merupakan pernikahan yang lain. ${ }^{8}$

Menurut Abi Ishak Ibrahim Bin Ali Bin Yusuf Alfairuzzabadi Asyairoji dalam kitabnya Al Muhadzab Fii Fiqhi Al Imam As Syafii ( jilid $2: 441$ ) bahwa menggabungkan diantara dua saudara atau diantara wanita dan bibinya dari pihak ayah atau diantara wanita dan bibi dari pihak ibu dalam satu akad, batallah pernikahanya. Karena salah satu diantara keduanya tidak saling mengungguli. Seorang laki-laki menikahi salah satu diantara keduanya setelah yg lain, batalah pernikahan yang kedua karena wanita tersebut masuk kedalam kemahraman. berbeda permasalahan seseorang menikahi salah satu diantara keduanya kemudian mentalaknya jika talak tersebut ba'in halal baginya karna ia tidak menggabungkan keduanya dalam satu kasur, tapi jika talak tersebut raj'i haram baginya karna masih dalam satu kasur. Jika seorang musyrik menikahi wanita musyrik berjima dengannya kemudian masuk Islam dan menikahi saudarinya tidaklah sah. ${ }^{9} \mathrm{Al}$ maszni berkata pernikahan itu bergantung atas keislaman wanita, maka jika ia belum masuk Islam sampai habis masa iddahnya sah baginya. Oleh karna itu halal pernikahan wanita musyrik atas habisnya masa iddah dan haram menikahinya dalam keadaan Islam.

Menurut Muhammad Bin Muhammad Bin Muhammad Al Ghazali dalam kitabnya Al Wasit Fil Madzhab (jilid 5 : 110) bahwa ada perbedaan pendapat dalam masalah pernikahan saudari wanita yang di talak raj'i atau ba'in dan pernikahan kelima setelah mentalaq istrinya yang keempat: (a) Madzhab Syafiiyah, boleh seorang laki-laki menikahi saudari istrinya yang ditalak apabila talakba'in meskipun masa iddahnya belum habis. (b) MadzhabMalikiyah, boleh seorang laki-laki mentalak salah satu dari istri-istrinya yang keempat secara talakba'in, kemudian menikahi wanita lain meskipun belum habis masa iddahnya. (c) Madzhab Hanafiyah, tidak boleh seseorang menikahi saudari istrinya yang ditalaq dalam masa iddahnya, meskipun itu talaq raj'i ataupun talaq ba'in. (d) Madzhab Hanabilah tidak boleh seseorang menikahi wanita dalam masa iddah istrinya yang keempat, baik itu talakraj'i ataupun ba'in. ${ }^{10}$

Adapun Hadits yang memuat keterangan mengenai haramnya perkawinan jam'u bainal ukhtain adalah sebagai berikut.

$$
\begin{aligned}
& \text { حدثنا عبد الله بن يوسف حدثنا الليث عن عقيل عن ابن شهاب أن عروة بن الزبير أخبره أن زينب ابنة أبي سلمة أخبرته أن }
\end{aligned}
$$

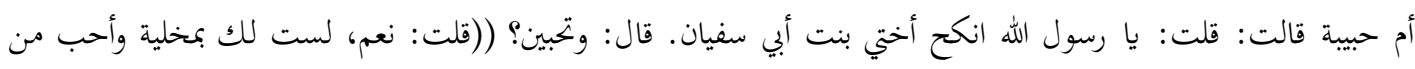




$$
\begin{aligned}
& \text { شاركني في خير أختي. فقال النبي ص.م: إن ذلك لا يحل لي. قلت: يا رسول الله، فو الله إن لنتحدث أنك تريد أن تنكح درة }
\end{aligned}
$$

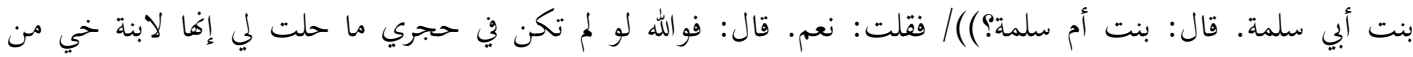

$$
\begin{aligned}
& \text { الرضاعة، أرضعتني وأبا سلمة ثوية، فلا تعرضن علي بناتكن ولا أخواتكن. (رواه البخاري). }
\end{aligned}
$$

"Diceritakan kepada kami Abdullah bin Yusuf, Diceritakan kepada kami Al-Laits dari 'Uqail dari Ibnu Syihab bahwa sesungguhnya Urwah bin Zubair memberitakan kepadanya bahwa sesungguhnya Zainab binti Abi Salamah memberitakan kepadanya bahwa Ummu Habibah berkata: Aku bekata: Wahai Rasulullah nikahilah saudara perempuanku Binta Abi Sufyan. Rasulullah menjawab: Apakah ia suka? Aku berkata: Ya. Aku tidak memiliki kebebasan bagimu dan yang paling disukai seseorang yang mengikutiku dalam kebaikan saudara perempuanku. Maka Nabi SAW berkata: ((Sesungguhnya itu tidak halal bagiku)). Aku berkata: Wahai Rasulullah, demi Allah sesungguhnya kami mengatakan bahwa engkau menikahi Durrah binta Abi Salamah. Rasulullah berkata: Binti Umma Salamah?, maka aku berkata: Ya. Rasulullah bersabda: Demi Allah andaikan ia belum berada dalam laranganku maka ia halal bagiku, sesungguhnya ia benar anak perempuan dari saudara sepersusuanku, Suaibah telah menyusuiku bersama Aba Salamah, maka janganlah kalian menampakan padaku anak-anakmu dan saudara-saudara perempuanmu." (H.R. Bukhari)

Menurut Abdurrahman bin Al-Barrak dalam kitab Fathul Al-BaribiSyarhiShahih AlBukhari Jilid 11, Dijelaskan dari Hadits Ummu Habibah tersebut dari perkataan Nabi "Janganlah kalian menampakan padaku anak-anakmu dan saudara-saudara perempuanmu", bahwa menggabungkan dua saudara dalam pernikahan haram secara ijma baik kedua saudara itu dari segi sekandung, sebapak atau seibu, baik dari segi nasab maupun sepersusuan. Ulama berbeda pedapat jika kedua saudara tersebut adalah budak. Maka sebagian salaf membolehkannya dari riwayat Ahmad dan Jumhur sedangkan Fuqoha mesir melarangnya, padanannya menggabungkan perempuan bersama bibinya (dari pihak ayah atau ibu) yaitu Al-Tsauri menceritakannya dari Syi'ah. ${ }^{11}$

Larangan perkawinan semenda, larangan yang terkait dengan perkawinan sebelumnya, dapat dilihat dalam Os. An-nisa ayat 22 , yaitu :

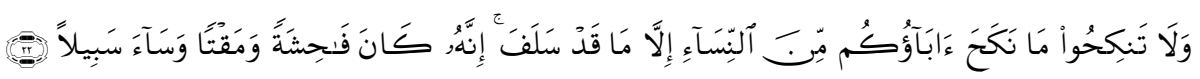

"dan janganlah kamu kawini wanita-wanita yang telah dikawini oleh ayahmu, terkecuali pada masa yang telah lampau. Sesungguhnya perbuatan itu Amat keji dan dibenci Allah dan seburuk-buruk jalan (yang ditempuh).".

Tidak hanya bersifat larangan, hal di atas memiliki hukum haram juga, dengan adanya petunjuk ('illah) bahwa perbuatan itu adalah perbuatan jahat dan keji. ${ }^{12}$ Untuk masalah perkawinan, Allah SWT memberikan syari'at atau aturan diberikan kepada umat

\footnotetext{
${ }^{11}$ Ibnu Hajar Al-'Asqalany, Fath al-Bâ ry, Juz IV, (Madînah : al Maktabah al-Salâfiyyah, T.th) hlm. 405

${ }^{12}$ Mulati, Hukum Perkawinan Islam, (Tangerang : Pustaka Mandiri, 2012) hlm. 37
} 
manusia untuk mendapat kebahagiaan hidup baik di dunia maupun di akhirat demi tercapainya maqasid al- syariat. ${ }^{13} \mathrm{Di}$ antara aturan tersebut ialah seorang wanita mana yang boleh dikawini oleh seorang pria dan yang tidak boleh dikawini. Wanita yang tidak boleh dikawini oleh seorang pria ada dua macam, yaitu: a) Karena ada larangan abadi (muabbad) yaitu karena pertalian nasab, kerabat semenda, saudara sesusuan. b) Karena ada larangan dalam waktu tertentu (muaqqat) atau larangan sementara. Larangan ini dibatalkan dengan adanya perubahan keadaan. Misalnya seorang laki-laki tidak boleh menikahi wanita yang telah bersuami, larangan ini hilang setelah perkawinan si wanita putus, baik karena ditinggal mati atau karena bercerai dan telah habis masa iddah. ${ }^{14}$

Di dalam fatwa Lajnah Daimah Lil Buhuuts wal Iftaa' disebutkan bahwa menggabungkan dua wanita bersaudara dalam satu akad hukumnya adalah haram, baik keduanya saudara kandung, saudara seayah atau seibu, saudara senasab atau sesusuan, yang merdeka ataupun hamba sahaya atau salah satu dari keduanya hamba sahaya dan yang lainnya sorang yang merdeka. Hal ini merupakan hasil ijma' dari kalangan para sahabat r.a, tabi'in beserta ulama salaf. Ibnu Mundzir juga meriwayatkan tentang ijma' dalam pembahasan tersebut. ${ }^{15}$

Pada umumnya, ulama' Ahlussunnah, diantaranya; empat ulama' madzhab, Ibnu Taimiyyah, Ibnu Qayyim Al-Jauziyyah, Imam An-Nawawy, Ibnu Hajar Al-Asqalany dan sebagainya sepakat haramnya pernikahan ini bila dilakukan dalam satu ikatan sekaligus. Sulaiman al-Asyqar berpendapat, jika seorang lelaki melakukannya dalam dua akad dan waktu yang sama, maka batal akad keduanya. Akan tetapi, jika akadnya dilakukan dalam waktu yang berbeda, maka batallah akad kedua, bukan pertama. Berbeda dengan pengarang kitab Ahkam az-Zawaj wa ath-Thalaq, jika akad dilakukan dalam akad yang sama, maka akadnyafasid(rusak), tidak ada yang lebih baik dan lebih utama dari keduanya. Jika dilakukan dalam dua akad, maka batal pernikahan yang kedua, dan sah pernikahan yang pertama, selama belum menggauli istri yang kedua. Dan baginya menjalani masa iddah. Ini menurut Hanafiyah. Begitu pula dengan Malikiyah, Syafi'iyah dan Hanabilah. ${ }^{16}$

Syaikh Bin Baaz di dalam fatwanya, "Tidak diperbolehkan bagi seorang lelaki yang sudah beristri kemudian menikahi keponakan dari istrinya tersebut selama istrinya masih dalam ikatannya. Karena Rasulullah SAW juga melarang mengumpulkan (menghimpun) seorang wanita dengan bibinya baik dari pihak ayah maupun ibunya. Sebagaimana para Ulama' sepakat atas haramnya hal tersebut yang ditinjau dari tinjauan hadits shahih, kecuali apabila sang bibi sudah meninggal atau telah dicerai dan usai menjalani 'iddah-

\footnotetext{
${ }^{13}$ Asafri Jaya Bakri, Konsep Maqasid syari'ah Menurut Al-Syatibi, (Jakarta : PT. Raja Grapindo Persada, 1996. HIm. 63

${ }^{14}$ Abdurrahman I. Doi, Karakteristik Hukum Islam dan Perkawinan, (Jakarta : Raja Grafindo Persada, 1996) hlm. 20-21

${ }^{15}$ Mohd Idris Ramulyo, Hukum Perkawinan Islam, (Jakarta : Bumi Aksara, 1996) hlm. 80

${ }^{16}$ Sastroatmojo, Arso dan A. Wasit Aulawi, Hukum Perkawinan Di Indonesia, (Medan : Bulan Bintang, 1975) hlm. 30
} 
nya, maka diperbolehkan menikahi keponakan tersebut, karena sudah tidak berkumpul kembali. ${ }^{17}$

Menurut Rahmat Hakim, dalam Kompilasi Hukum Islam, wanita-wanita yang haram dinikahi dimasukan dalam Bab VI pasal 39 sampai 44 dijelaskan pula tentang wanita-wanita yang haram dinikahi. Pada prinsipnya, seluruh pasal yang menyangkut larangan menikah ini, selaras dengan apa yang diutarakan dalam fiqih. ${ }^{18}$

\section{Pernikahan Jam'u Bainal Ukhtain di Desa Sukasenang Kecamatan Banyuresmi Kabupaten Garut}

Kejadian pernikahan perkawinan jam'u bainal ukhtain di Desa Sukasenang, Garut diawali ketika lelaki yang berinisial $A(L)$ berniat untuk menikahi I $(P)$ dan kemudian pergi menemui kedua orangtuanya I (P) di kediamannya. Namun, ketika mengutarakan maksud dan tujuan kedatangannya tersebut, orang tua I (P) memberikan pernyataan kepada A (L) bahwa I (P) memiliki seorang kakak yang berinisial $N(P)$ yang belum menikah. Menurut kepercayaan orang tua dari I $(P)$ dan $N(P)$, dalam adat sunda dikenal istilah ngarunghal yaitu keadaan dimana seorang adik perempuan menikah mendahului kakaknya, dan hal tersebut dianggap tidak baik. Apa yang dilakukan oleh orangtua I (P) dan N (P) pada saat itu mengikuti keyakinan yang mereka anggap baik. Orangtua I (P) dan $N(P)$ berkata ngarunghal saja sudah tidak baik, apalagi yang didahuluinya adalah seorang perempuan. ${ }^{19}$ Mereka meyakini bahwa anak perempuan yang di dahului pernikahannya oleh adiknya sendiri terutama kakaknya seorang perempuan, akan susah untuk menikah, kemudian sering melamun hingga sampai sakit, bahkan kejiwaannya bisa sampai menjadi terganggu. ${ }^{20}$

Atas dasar tersebut, orang tua I (P) dan N (P) menyarankan agar $A(L)$ menikahi $N$ $(P)$ terlebih dahulu. A ( $L)$ bersedia untuk menikahi $N(P)$ yang dilakukan di depan penghulu dan tercatat di KUA setempat.

\section{Proses Pernikahan A dengan $\mathbf{N}$}

Proses pernikahan antara A dengan $\mathrm{N}$ berlangsung secara terbuka artinya dilakukan dengan adanya resepsi. Rukun dan syaratnya terpenuhi perkawinan berdasarkan kesepakatan jumhur ulama yaitu adanya wali, saksi, calon mempelai wanita dan calon mempelai pria kemudian adanya proses akad yaitu ijab qabul seperti apa yang disampaikan oleh Abdul Rahman Ghozali dalam bukunya yang berjudul Fiqih Munakahat. ${ }^{21}$ Pernikahan antara A (L) dengan N (P) dihadiri oleh wali yang berinisial IS dan dua orang

\footnotetext{
${ }^{17}$ Abdul Mutaal Muhammad Al Jabry, Perkawinan Campuran Menurut Pandangan Islam, (Jakarta : PT. Bulan Bintang, 1991) hlm 30)

${ }^{18}$ Rahmat Hakim, Hukum Perkawinan Islam, (Bandung : Pustaka Setia, 1999) hlm. 57

${ }^{19}$ Wawancara dengan I, oleh Ilham Abdul Kholid, tanggal, 2 Juni 2016

${ }^{20}$ Wawancara dengan N, oleh Ilham Abdul Kholid, tanggal, 25 Mei 2016

${ }^{21}$ Abdul Rahman Ghozali, Fiqh Munakahat, (Jakarta : Kencana, 2003) hlm. 45
} 
saksi yang berinisial $\mathrm{AH}$ dan $\mathrm{AN}$, kemudian $\mathrm{A}$ dengan $\mathrm{N}$ melangsungkan akad nikah pada Bulan Oktober, Tahun 1991.

Selain itu pPernikahan antara $A(L)$ dengan $N(P)$ dilakukan melalui proses pendaftaran dan pencatatan di KUA setempat, meliputi pemberitahuan kehendak nikah, pemeriksaan nikah, pengumuman kehendak nikah, akad nikah dan penandatanganan akta nikah serta pembuatan kutipan akta nikah. Orang yang hendak menikah memberitahukan kehendaknya kepada Pembantu Pegawai Pencatat Nikah ( $\left.\mathrm{P}_{3} \mathrm{~N}\right)$ yang berwenang di tempat dilangsungkannya akad nikah. Hal ini dilakukan sekurang-kurangnya sepuluh hari kerja sebelum akad nikah dilangsungkan.

\section{Proses Pernikahan A dengan I}

Adapun proses pernikahan A dengan I berlangsung tertutup yang artinya tidak adanya resepsi pernikahan karena I hamil di luar perkawinan yang sah, kemudian pernikahan antara A dengan I dilangsungkan secara diam-diam pada malam haridi bulan April 1997 dan dilaksanakan oleh salah satu tokoh Agama di daerah tersebut berinisial AB dan hanya disaksikan oleh satu orang saksi berinisial $S$, serta tanpa kehadiran wali. Pernikahan A dengan I ini hanya dilaksanakan di bawah tangan atau tidak tercatat serta tidak memenuhi rukun dan syaratnya. Di samping itu, tidak adanya keterbukaan dari $\mathrm{A}$ dengan I mengenai status perkawinan $\mathrm{A}$ dan hubungan kekerabatan antara I dan $\mathrm{N}$ yang merupakan istri dari $\mathrm{A}$. Pada saat itu, baik $\mathrm{AB}$ maupun $\mathrm{S}$ tidak mengetahui hubungan tersebut.

Proses pernikahan ini sudah jelas tidak sesuai dengan apa yang terpapar dalam Kompilasi Hukum Islam (KHI) BAB II mengenai Dasar-Dasar Perkawinan pasal 5 yang berbunyi "agar terjamin ketertiban bagi masyarakat Islam setiap perkawinan harus dicatat". Kemudian di poin berikutnya disebutkan bahwa "pencatatan perkawinan tersebut pada ayat (1) dilakukan oleh pegawai pencatat nikah." Selanjutnya di dalam BAB IV juga tercantum bahwa mengenai rukun dan syarat perkawinan ialah " calon suami, calon istri, wali nikah, dua orang saksi dan ijab kabul" ${ }^{22}$

\section{Akibat Hukum Dari Pernikahan Jam'u Bainal Ukhtain yang Terjadi di Desa Sukasenang Kecamatan Banyuresmi Kabupaten Garut}

Pernikahan antara $A(L)$ dengan N (P) dinyatakan sah baik secara agama maupun peraturan perundang-undangan, karena perkawinan mereka dilakukan sesuai dengan Hukum Islam dan dicatat di KUA sebagaimana yang ditentukan dalam UU Perkawinan pasal 2 ayat 2 dinyatakan bahwa "tiap-tiap perkawinan dicatat menurut peraturan perundang-undangan yang berlaku", kemudian dalam pasal $5 \mathrm{KHI}$ yang menyatakan :

"Agar terjamin ketertiban perkawinan bagi masyarakat Islam, setiap perkawinan harus di catat. Pencatatan perkawinan tersebut pada ayat (1) dilakukan oleh

\footnotetext{
${ }^{22}$ Wawancara dengan S, oleh (Ilham Abdul Kholid) pada tanggal 9 mei 2016
} 
pegawai pencatat Nikah sebagaimana yang diatur dalam Undang-undang No. 22 tahun 1946 jo. Undang-undang Nomor 32 tahun 1954".

Selanjutnya pada pasal 6 juga dijelaskan,

"untuk memenuhi ketentuan dalam pasal 5, setiap perkawinan harus dilangsungkan dihadapan dan di bawah pengawasan pegawai pencatat Nikah. Perkawinan yang dilakukan di luar pengawasan pegawai pencatat Nikah tidak mempunyai kekuatan Hukum". ${ }^{23}$

Sehingga pasangan $A(L)$ dengan $N(P)$ memiliki akta nikah dengan kutipan akta nikah Nomor 463 / 30 /IX / 1991 dan selama pernikahan A (L) dengan N (P) dikarunia 2 anak yaitu laki-laki dan perempuan ${ }^{24}$.

Adapun status pernikahan antara A dengan I batal hukumnya karena I termasuk ke dalam muharramat yaitu wanita yang haram dinikahi secara muaqqat yaitu haram sementara, seperti menurut Al Hamdani bahwa larangan kawin dengan seorang perempuan itu ada dua macam, pertama larangan muabbad, yaitu larangan untuk dikawin selamanya. Kedua, larangan muaqqat, yaitu larangan kawin dengan seorang perempuan selama perempuan tersebut masih dalam keadaan tertentu. Apabila keadaaan itu berubah maka larangan itu tercabut dan perempuan itu menjadi halal di kawin. ${ }^{25}$

Adapun dari pernikahan yang dilakukan oleh A dengan I mengakibatkan konsekuensi terhadap I, yaitu I tidak dianggap sebagai istri sah A selaku suaminya karena tidak mempunyai akta nikah sebagai bukti bahwa $A$ adalah suami I. Menurut Abdul Manan bahwa akibat hukum pernikahan yang tidak dicatat antara lain: ${ }^{26}$

"(a) Suami istri tersebut tidak mempunyai akta nikah sebagai bukti mereka telah menikah secara sah menurut agama dan negara; (b) Anak-anak tidak dapat memperoleh akta kelahiran dari istri yang berwenang karena untuk mendapatkan akta kelahiran diperlukan akta nikah dari orangtuanya; (c) Anak-anak tidak dapat mewarisi harta orang tuanya karena tidak ada bukti autentik yang menyatakan mereka sebagai ahli waris orangtuanya; (d) Tidak memperoleh hak-hak lainnya dalam pelaksanaan administrasi negara yang mesti harus dipenuhi sebagai bukti diri."

Selain itu dampak dari perkawinan yang tidak sah ini berdampak bukan hanya bagi I, namun juga berdampak kepada keturunannya yaitu AR selaku anak dari A dengan I. Status anak yang dilahirkan dari pernikahan yang tidak sah, maka dianggap anak yang

\footnotetext{
${ }^{23}$ Abdurrahman, Kompilasi Hukum Islam, Cet. 4, (Jakarta: Akamedika Pressindo, 2004)

${ }^{24}$ wawancara dengan N, oleh Ilham Abdul Kholid, tanggal25 mei 2016

${ }^{25}$ Al Hamdani, Risalah Nikah (Hukum Perkawinan Islam), Jakarta : Pustaka Amani, 2002) hlm. 83

${ }^{26}$ Abdul Manan, Aneka Masalah Hukum Perdata Islam di Indonesia, (Jakarta : Kencana, 2006) hlm. 47-
} 
tidak sah. Bahwa Konsekuensinya seperti yang tercantum dalam pasal $100 \mathrm{KHI}$ bahwa "..anak hanya mempunyai hubungan perdata dengan ibu dan keluarga ibu". Artinya AR tidak mempunyai hubungan atau keperdataan hukum terhadap A selaku ayahnya. Berdasarkan pasal 42 sampai dengan pasal 44 UU perkawinan, kedudukan anak dibagi ke dalam dua kelompok yaitu: 1) Anak yang sah, dan 2) Anak yang dilahirkan di luar perkawinan. Berdasarkan pasal 42 "Anak yang sah adalah anak yang dilahirkan dalam atau sebagai akibat perkawinan yang sah." Artinya anak yang dilahirkan dalam perkawinan yang tidak sah dianggap anak yang lahir di luar perkawinan sebagaiman diatur dalam pasal 43 ayat (1) undang-undang tersebut dan "... hanya memiliki hubungan perdata dengan ibunya dan keluarga ibunya".

Sementara itu mengenai waris pun tidak ada ikatan saling mewarisi antara AR dengan A selaku ayahnya, karena tidak memiliki sebab kewarisan sebagai ahli waris yang sah seperti yang tercantum di dalam KHI pasal 171 huruf c yang menyatakan bahwa "... ahli waris adalah orang pada saat meninggal dunia mempunyai hubungan darah atau hubungan perkawinan dengan pewaris, beragama Islam dan tidak terhalang karena hukum untuk menjadi ahli waris". Seperti apa yang disampaikan Siah Khosyi'ah adanya pengahalang kewarisan, karena setiap orang juga yang masih dalam kandungan kalau ia lahir dalam keadaan hidup mempunyai hak untuk mewarisi kecuali ada hal-hal yang menyebabkan orang-orang tertentu dengan tindakan-tindakan dan keadaan-keadaan yang dapat menggugurkan hak seseorang untuk memperoleh waris. ${ }^{27}$

Kemudian tidak ada hak saling mewarisi ketika nikah dalam kondisi rusak, inilah yang telah disepakati oleh para ulama, karena nikah ini pada dasarnya tidak terlaksana, untuk tetapnya garis keturunan (nasab) anaknya juga tidak disandarkan kepada ayahnya ${ }^{28}$.

\section{Simpulan}

Latar belakang terjadinya pernikahan jam'u bainal ukhtain Terjadinya pernikahan antara I (P) dengan A ( $L$ ) pada saat itu diakibatkan karena adanya sebuah keyakinan yang keliru yaitu adanya adat ngarunghal, karena mengenai ngarunghal tersebut hanya orang-orang tertentu yang mempercayainya, salah satunya orangtua $N(P)$ dengan I $(P)$ yang meyakini bahwa ngarunghal adalah adat turun temurun dari orangtua dan nenek moyangnya, orang tua $N(P)$ dengan I $(P)$ meyakini bahwa anak perempuan yang di dahului pernikahannya oleh adiknya sendiri akan susah untuk menikah, kemudian sering melamun hingga sampai sakit, bahkan kejiwaannya bisa sampai menjadi terganggu. Kemudian selain dilatarbelakangi oleh adanya keyakinan yang keliru akan larangan ngarunghal, perkawinan jam'u bainal ukhtain juga dilatarbelakangi karena minimnya

\footnotetext{
${ }^{27}$ Siah Khosyi'ah, Hukum Kewarisan Islam, (Bandung Pusat Penelitian dan Penerbitan LP2M UIN Sunan Gunung Djati Bandung, 2015) hlm. 150

${ }^{28}$ Wahbah Azzuhaili, Figh Islam Wa Adillatuhu, Terj. Abdul Hayyie al-Kattani, dkk, Jakarta : Gema Insani, 2011) hlm. 108)
} 
pengetahuan Agama dan kurangnya pendidikan. Selain itu terjadinya perkawinan jam'u bainal ukhtain ini karena adanya penyembunyian identitas antara $A(L)$ dengan I $(P)$ bahwa I adalah adik ipar $\mathrm{A}$, karena I adalah adik kandung dari $\mathrm{N}$ yang masih berstatus istri sahnya A.

Proses pernikahan jam'u bainal ukhtain ini berlangsung dua kali proses, yaitu ketika A menikahi $\mathrm{N}$ yang berstatus kakaknya I, kemudian $\mathrm{A}$ menikahi I yang berstatus adik kandung dari $\mathrm{N}$ dan sekaligus menjadi adik ipar $\mathrm{A}$. Kemudian pernikahan pertama antara A dengan $\mathrm{N}$ berlangsung secara terbuka artinya dilakukan dengan adanya resepsi. Rukun dan syaratnya terpenuhi yaitu adanya wali, saksi, calon mempelai wanita dan calon mempelai pria kemudian adanya proses akad yaitu ijab qabul. Pernikahan antara A (L) dengan $N(P)$ di hadiri oleh wali yang berinisial IS dan dua orang saksi yang berinisial $\mathrm{AH}$ dan AN, kemudian A dengan N melangsungkan akad nikah pada Bulan Oktober, Tahun 1991. Selain itu pernikahan antara $A$ dengan $\mathrm{N}$ juga melalui proses pendaftaran di KUA setempat, yaitu tata cara atau proses pelaksanaan pencatatan nikah meliputi pemberitahuan kehendak nikah, pemeriksaan nikah, pengumuman kehendak nikah, akad nikah dan penandatanganan akta nikah serta pembuatan kutipan akta nikah.

Adapun proses pernikahan A dengan I berlangsung tertutup yang artinya tidak adanya resepsi pernikahan karena I hamil di luar perkawinan yang sah, kemudian pernikahan antara A dengan I dilangsungkan secara diam-diam pada malam hari, tanggal bulan April 1997 dan dilaksanakan oleh salah satu tokoh Agama setempat dan hanya disaksikan oleh satu orang saksi. Pernikahan A dengan I ini hanya dilaksanakan di bawah tangan. Pernikahan A dan I tidak memenuhi rukun dan syarat pernikahan, tidak adanya keterbukaan dari A dengan I dengan status keduanya sehingga proses penikahsn tetap dilangsungkan.

Secara hukum pernikahan antara A ( $L$ ) dengan I (P) adalah haram, karena I termasuk ke dalam wanita muharramat atau wanita yang haram untuk dinikahi oleh $\mathrm{A}$. Hubungan suami istri yang dilakukan oleh A dengan I sama dengan zina. Kemudian I tidak dianggap sebagai istri sah A selaku suaminya karena tidak mempunyai akta nikah sebagai bukti bahwa A adalah suami I. Status anak yang dilahirkan dari pernikahan ini dianggao anak yang lahir di luar perkawinan, sehingga anak tersebut hanya mempunyai hubungan perdata dengan ibu dan keluarga ibu. Tidak ada hak saling mewarisi antara I dan A karena pernikahan yang tidak sah, bahkan si anak tidak dapat menjadi ahli waris dari A karena terhalang oleh hukum atau terdapatnya hal atau tindakan yang dapat menggugurkan hak seseorang untuk memperoleh waris.

\section{Daftar Pustaka}

'Asqalany, Ibnu Hajar Al-, T.th. Fath al-Bâ ry, Juz IV, Madînah : al Maktabah al-Salâfiyyah Abdurrahman, 2004. Kompilasi Hukum Islam, Cet. 4, Jakarta : Akamedika Pressindo 
Al Ghazali, Muhammad bin Muhammad bin Muhammad, T.th. Kitab Al Wasif Fil Madzhab, Jilid 5

Ali Yusuf, Abu Ishaq Ibrahim bin. T.th. Al-Muhadzab fi al-Imam Asy-Syafi'l, Juz II, Dar alKitab al-Ilmiyah,

Al-Imroni, Abul Hasan Yahya bin Abul Khoir bin Salim, 2000. Al-Bayan FiMadzhabil Imam Asy-syafi'l, Darul Minhaj, Damaskus-Syiria, Cetakan Pertama.

Amiruddin, Aam, 2012. Al-Quran Al-Mu'asir, Terjemah Kontemporer, Bandung: Khazanah, Intelektual.

Asy-Syafi'l, 2001. al-Umm, Beirut : Dar al-Kutub al-Ilmiah

Azzuhaili, Wahbah, 2011. Fiqh Islam Wa Adillatuhu, Terj. Abdul Hayyie al-Kattani, dkk, Jakarta : Gema Insani,

Bakri, Asafri Jaya, 1996. Konsep Maqasid syari'ah Menurut Al-Syatibi, Jakarta : PT. Raja Grapindo Persada,

Fachruddin, Fuad Mohd. 1992. Masalah Anak dalam Hukum Islam (Anak Kandung, Anak Tiri, Anak Angkat dan Anak Zina). CV. Pedoman Ilmu Jaya.

Ghozali, Abdul Rahman, 2003. Fiqh Munakahat, Jakarta : Kencana,

Ghozali, Abdul Rahman, 2010. Fiqih Munakahat, Jakarta, Kencana Prenada Media Group. Hadikusuma, Hilman. 1990. Hukum Perkawinan Adat, Bandung : Citra Aditya Bakti, Hakim, Rahmat, 1999. Hukum Perkawinan Islam, Bandung : Pustaka Setia, Hamdani, Al, 2002. Risalah Nikah (Hukum Perkawinan Islam), Jakarta : Pustaka Amani, I. Doi, Abdurrahman, 1996, Karakteristik Hukum Islam dan Perkawinan, Jakarta : Raja Grafindo Persada,

Ismail, Muhammad Bakr, 1990. Al-Fiqh Al Wadhih, Juz 2, Kairo : Dar al-Manar, Jabry, Abdul Mutaal Muhammad Al, 1991. Perkawinan Campuran Menurut Pandangan Islam, Jakarta : PT. Bulan Bintang,

Khosyi'ah, Siah, 2015. Hukum Kewarisan Islam, (Bandung Pusat Penelitian dan Penerbitan LP2 M UIN Sunan Gunung Djati Bandung,

Manan, Abdul, 2006. Aneka Masalah Hukum Perdata Islam di Indonesia, Jakarta : Kencana

Mulati, 2012. Hukum Perkawinan Islam, Tangerang : Pustaka Mandiri, Ramulyo, Mohd Idris, 1996. Hukum Perkawinan Islam, Jakarta : Bumi Aksara, Sastroatmojo, Arso dan Aulawi, A. Wasit. 1975. Hukum Perkawinan Di Indonesia, Medan : Bulan Bintang,

Subekti, R. dan Tjitrousibio, R., 2003. Kitab Undang Undang Hukum Perdata (KUH Perdata), Jakarta : Pradnya Paramita.

Wawancara dengan I, oleh Ilham Abdul Kholid, tanggal, 2 Juni 2016 Wawancara dengan N, oleh Ilham Abdul Kholid, tanggal, 25 Mei 2016 Wawancara dengan S, oleh Ilham Abdul Kholid, pada tanggal 9 mei 2016 Wawancara dengan N, oleh Ilham Abdul Kholid, tanggal25 mei 2016 